\title{
DÜBLIN
}

Technological University Dublin

ARROW@TU Dublin

\section{A Reflection on Teachers' Experience as E-learners}

\author{
Claire M. Mc Donnell \\ Technological University Dublin, claire.mcdonnell@tudublin.ie \\ Tony Cunningham \\ Technological University Dublin, tony.cunningham@tudublin.ie \\ Barry Mclntyre \\ Dun Laoghaire Institute of Art, Design and Technology, Barry.McIntyre@iadt.ie
}

See next page for additional authors

Follow this and additional works at: https://arrow.tudublin.ie/scschcpsbk

Part of the Educational Assessment, Evaluation, and Research Commons, and the Higher Education and Teaching Commons

\section{Recommended Citation}

Cunningham, T., McDonnell, C., \& McIntyre, B. (2008). A Reflection on Teachers' Experience as E-Learners. In R. Donnelly and F. Mc Sweeney (Eds), Applied E-Learning and E-Teaching in Higher Education, pg. 78-105. Pennsylvania, USA: Information Science Reference. doi:10.4018/978-1-59904-814-7.ch004

This Book Chapter is brought to you for free and open access by the School of Chemical and Pharmaceutical Sciences at ARROW@TU Dublin. It has been accepted for inclusion in Books/Book chapters by an authorized administrator of ARROW@TU Dublin. For more information, please contact arrow.admin@tudublin.ie, aisling.coyne@tudublin.ie,gerard.connolly@tudublin.ie.

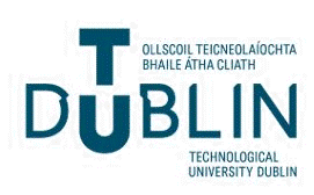


Authors

Claire M. Mc Donnell, Tony Cunningham, Barry McIntyre, and Theresa McKenna

This book chapter is available at ARROW@TU Dublin: https://arrow.tudublin.ie/scschcpsbk/1 


\title{
A REFLECTION ON TEACHERS' EXPERIENCE AS E-LEARNERS
}

Tony Cunningham,

School of Real Estate and Construction Economics,

Dublin Institute of Technology (DIT), Ireland.

Claire Mc Donnell,

School of Chemical and Pharmaceutical Sciences,

Dublin Institute of Technology (DIT), Ireland.

Barry McIntyre,

School of Business and Humanities,

Dun Laoghaire Institute of Art, Design and Technology (IADT), Ireland.

Theresa Mc Kenna,

National College of Art and Design (NCAD), Ireland.

\begin{abstract}
This chapter explores the insights gained by a group of teachers from their lived experience as eLearners participating in a blended module on Designing eLearning. An understanding of the student perspective on online learning was obtained but we were also able to reflect on our participation in the module on the basis of our other roles; as teachers and potential eTutors and as course designers. As a result, important considerations were identified for the design and facilitation of online courses. These include; the support provided to online learners, particularly over the first few weeks, appropriate assessment methods, facilitation of online collaboration, access to the Internet, time management and contextualising and scaffolding learning activities. Some issues relating to implementation of effective eLearning in Higher Education Institutions were also considered. Our lived experience as eLearners was invaluable to our development as eTutors and module designers and this approach is strongly recommended to achieve effective learning on how to be an effective online tutor and facilitator and how to design and develop online programmes and activities that make full use of the strengths of online learning.
\end{abstract}

\section{KEYWORDS}

Asynchronous Discussion, Case Study, Collaborative Learning, Education Research, Electronic Learning (E-Learning), Higher Education, Internet Access, Online Teaching, Synchronous Communication, Technology Training, Web Course Development, Web-Based Interactions. 


\section{A REFLECTION ON TEACHERS’ EXPERIENCE AS E-LEARNERS}

\section{INTRODUCTION}

The authors recently participated in a ten week blended learning module entitled Designing eLearning as part of the Postgraduate Diploma in Third Level Learning and Teaching in the Dublin Institute of Technology (DIT), Ireland. This module allowed us to experience eLearning from the student perspective in order to help us to develop as eTutors and course designers. In total, seven academic staff from a range of disciplines and a number of Irish third level colleges took part. Most had only experienced learning online before to a very limited extent (accessing course material in a virtual learning environment (VLE)) and two were implementing blended delivery of modules within programmes. The diverse background, experience, knowledge and confidence among our group of eLearners meant that a wide range of issues and problems that online learners and tutors encounter in practice were brought to our attention.

In this chapter, we examine the insights we gained into blended learning from a student's perspective and review the current literature in this area. We also discuss our experience from the perspective of our other roles; as teachers and potential eTutors and as course designers. We consider the support provided to online learners, the appropriateness of assessment methods used, the range of eLearning methods experienced and the problems encountered as well as our reflections on the strengths and shortcomings of the eLearning environment. Finally, future trends and research directions are discussed.

\section{BACKGROUND}

What is Blended Learning?

Throughout this chapter, the term blended learning is used to describe course delivery in which a combination of face-to-face and online teaching and learning take place. Holmes and Gardner (2006:153) state that the rationale behind this approach is to improve traditional learning environments by incorporating eLearning where appropriate. Thus, eLearning is employed to complement other methods, not replace them, and should only be used if it enriches and enhances what is already being done (Charlesworth and Vician, 2003). Singh and Reed (2001) maintain that variation in the 'blend' selected allows a programme of study to be tailored to the particular needs of the learner:

"Blended learning focuses on optimizing achievement of learning objectives by applying the "right" learning technologies to match the "right" personal learning style to transfer the "right" skills to the "right" person at the "right" time" (p. 2).

There are several other interpretations of what blended learning involves, including one that views it as a blend of different types of web-based tools and media only (Whitelock \& Jelfs, 2003) and another proposed by Driscoll (2002) that describes mixing several pedagogical approaches which may or may not include instructional technology.

In a recent review, Sharpe et al. (2006:4) recognise that blended learning is not easy to define. However, they recommend that the use of the term is continued because this lack of clarity allows teaching staff to develop their own particular meaning 
appropriate to their context. They also contend that academic staff are reassured by the implication that face-to-face contact with students is preserved in a blended learning approach. Oliver \& Trigwell (2005) are of the opposite opinion however. They argue that use of the term should be discontinued because of the problem of clarity and also because none of the interpretations include the perspective of the learner. They suggest that a move towards a student perspective would be facilitated by employing a variation theory research framework. We believe that the expression blended learning has now entered into relatively widespread use and that it is not practical at this stage to abandon it. However, the issue raised by Oliver and Trigwell (2005) of the need to incorporate the student perspective is a very important one and will be addressed further in this chapter.

\section{Students' Experience of Blended Learning}

As we are reporting on our own lived experience as eLearners, it is pertinent to examine the existing literature on blended learning from a student perspective. Sharpe and Benfield (2005) and Beetham (2005) have identified a lack of research exploring eLearning from the learner's perspective and emphasise that knowledge in this area is essential to underpin the development of teaching methods that incorporate learning technology. Sharpe and Benfield (2005) comment that research has concentrated on the teacher perspective and on demonstrating the pedagogic worth of online learning but that this is understandable due to the relatively recent introduction of eLearning and a preoccupation with justifying the financial investment involved.

Sharpe, Benfield, Roberts and Francis (2006) carried out a wide ranging review of UK literature and practice on the undergraduate experience of blended eLearning in which they classified two main approaches adopted in higher education institutions. The first is the provision of additional support material online, which they report has been termed 'eTeaching' (Jones \& Fitzgibbon, 2002, as cited in Sharpe et al., 2006). The second, less common one involves course redesign to promote learner communication and interaction using information and communication technology (ICT). Sharpe et al. (2006) found that learners gave a positive response in almost all cases when asked about their opinion of supplementary material being made available online to support traditional teaching. The students rated course notes as the most useful resource and are appreciative of the flexibility afforded by online access.

However, the research by Sharpe et al. (2006) showed that, in the case of redesigned courses which incorporated activities supported by technology, significant differences between individual student experiences were reported and they contend that a variation in how students view their involvement in the learning process may be an important factor. A study by Concannon, Flynn and Campbell (2005) supports this argument. They found that individual factors such as motivation, clear career plans, peer influence and study strategy had a significant effect on students' use of and attitude to online learning and they point out that these are generic issues not directly related to the use of technology. They also established that, as well as a broad variation in their willingness to use ICT for learning existing between students, that, even within individual learners, there was inconsistency as their attitudes varied from context to context. As a consequence, Sharpe et al. (2006) contend that course designers should aim to be "developing environments in which all learners are encouraged to learn actively and deeply" (p. 72).

Quite a number of examples of inconsistency in learner responses to blended learning have been reported in the literature. In one study on online collaborative groups, it 
was found that some students saw the benefit of being able to provide more reflective and considered contributions online while others were concerned by the amount of time required to be effective participants in discussions. Also, some students were appreciative of the opportunity to learn from collaborative peer discussions moderated by a tutor but there were others who expected that the tutor would provide a model answer and were perturbed when this did not happen (Sweeney, O'Donoghue \& Whitehead, 2004). In relation to online support, Matheos, Daniel and McCalla (2005) report that half of the cohort of students in their study expressed a preference for learning support to be provided face-to-face by a person while the other half said that they would choose other kinds of support.

Often, issues that arise can be a result of the redesign of courses and the use of less traditional types of teaching and learning methods that accompany the introduction of blended learning rather than the learning technology itself. Sharpe et al. (2006) refer to the example reported by Clouder and Deepwell (2004) of a group of physiotherapy students on placement who posted accounts of critical incidents in a discussion forum but showed great reticence to comment on other students' work. Clouder and Deepwell (2004) observed that this problem was likely to be as a result of this group of learners not having experienced peer assessment before. Morris (2007) reports that allowing undergraduates the facility to post questions anonymously helps greatly to develop their confidence in an online environment. In a similar way, providing the opportunity to give online feedback to peers anonymously initially might prove to be a useful method of introducing them to peer assessment.

An area that requires careful consideration is online communication and collaboration as the dynamics of group interaction online are not yet fully understood (McConnell, 2005). Quinney (2005) describes how learners experienced a website set up to facilitate communication and to support integration of theory and practice for social work students on placement. It was found that the discussion board was used extensively as a means of continuing collaborative learning relationships that students had established before they began their placement as well as organising and planning academic assignments. Quinney (2005) reports that very little in-depth discussion occurred online, however, and that the students said that this took place when they spoke to each other instead. A requirement to show evidence of reflection and critical analysis in their online interaction as part of their course assessment might result in an improvement in the depth of the postings in the future. Quinney (2005) also identifies a valuable topic for future research as she makes the point that a detailed examination of the views of the students who did not use the discussion forum would have provided valuable insights. Stracke (2007) has examined this area and focused her research on the students who dropped out of a blended language learning programme. It was found that the students' perception of a lack of support and linkage between the face-to-face and computer-mediated parts of the programme as well as a rejection of the use of computers as tools for language learning were the main factors that influenced their decision to leave.

Prior experience of using ICT and attitudes towards computers are identified by Sharpe et al. (2006) as two major factors that influence the student experience of blended learning. Arbaugh (2004) carried out a study which showed that learners became more positive about online work as they experienced more courses that used it. He observed that a significant increase in the learning quality and effectiveness perceived by students occurred between the first and second online course. This emphasises the importance of tutors ensuring that they build the confidence of those 
with little ICT experience and providing effective support. In their research, Conole, de Laat, Dillon and Darby (2006) found that most students now use a range of technology, including laptops, MP3 players, memory sticks and mobile phones, in a variety of ways, to support different aspects of their learning, and that they are comfortable with these tools. This is reflected in their comment that a number of students in the research they undertook rejected the term 'eLearning' and preferred to just use 'learning' on the basis that ICT has always been an integral part of all aspects their lives. However, Conole et al. (2006) point out that learners with good ICT skills often lack eLiteracy and need to be shown how to develop the skills required to critically evaluate online sources and information.

It has been shown that there is a need for more research on students' perceptions of blended learning. The work that has been carried out to date demonstrates that students are generally positive about provision of extra resources and increased flexibility but that when online collaboration and communication is introduced, significant variations in the individual learner experiences have been observed. A number of factors that contribute have been identified and they include prior experience of and attitudes to computers and variations in how students view their involvement in the learning process.

\section{Experiencing Blended Learning as Students to Develop Online Tutoring Skills}

Munro and Walsh (2005) observe that, because online tutoring is a recent development, many academic staff did not experience it themselves as students and thus they tend to feel uncomfortable about tutoring in a web-based environment. This was also the case for our group and one participant identified that they wanted to gain experience of the use of discussion boards in the pre-module questionnaire they completed:

"I chose the Designing eLearning module because I want to spend some time developing online materials, find out more about what can be done and try out different ways of using eLearning e.g. discussion boards." (Participant D, response to pre-module questionnaire on prior experience of eLearning, January 2006)

Salmon (2000) recommends that the experience of being a student in an online environment is the most effective way to acquire the skills required to manage and facilitate online synchronous and asynchronous communication. Smith (2005) also states that the challenges online students face can best be understood using this approach. Smith (2001) examined the skills and competences required to be an eTutor and compared them with those necessary for tutoring face-to-face. She contends that although some of the skills are different, an experienced face-to-face tutor has many of the basic competences and should not find the transition to a web-based environment too difficult provided suitable training and guidance is available.

Munro and Walsh (2005) report that the participants on their course to train online tutors using a web-based environment commented that personal reflections were one of the most useful aspects of the course. To date, apart from the findings summarised here, very little else has been reported in the literature on the experience of students on online tutoring courses.

\section{CASE STUDY: THE DESIGNING E-LEARNING MODULE}

The DIT Postgraduate Diploma module in Designing eLearning that our group undertook provided an introduction to the theory and practice of online teaching and 
the development of online learning materials. Assessment was by means of a collaborative project-based learning project and an individual reflective paper.

\section{Prior Experience of Participants}

Before our Designing eLearning module began, we were asked to fill out a questionnaire sent by email on our previous experience of using ICT and of eLearning as students and teachers. This pre-module survey was designed to allow our tutor to prepare for our range of ICT skills levels. Due to a technical problem resulting in the non-delivery of the tutor's email, one of the students, who was a novice eLearner, did not receive the questionnaire. As it happened, this particular participant commented later when she saw the survey that, if she had tried to answer the questions, she would have become too anxious about her lack of experience and would have backed out of her decision to take the module. The rest of the participants who had some degree of ICT skills did not report this type of response to the questionnaire. From the perspective of an online tutor, it is worth noting therefore that participants who have very little computer experience will need additional reassurance and support, particularly just before and during their induction session (Salmon, 2000 and Sharpe et al., 2006). Responses from five of the course participants to an enquiry on their prior experience of eLearning, as learners and tutors, before they began the Designing eLearning course are provided in Appendix 1. It is evident that the level of familiarity with ICT and previous experience of eLearning of the participants varied greatly. One of the participants commented on their limited experience in their first discussion board posting:

"My experience with online technology is receiving and answering e-mails and even at that I could be better!" (Participant A, January 2006)

However, at the other end of the spectrum, two students on the module were developing blended delivery of some of the modules that they were teaching.

\section{Collaborative Learning Online}

The Designing e-Learning module was based primarily on collaborative ProjectBased Learning (CPBL). Our group was presented with a ten week open-ended task and we were required to design an online, activity-centred module that responded to a genuine learning need. The outputs specified were a group report and a developed web site including exemplars of online content. We produced a blended information literacy skills module that can now be modified for use by any of the group members and tailored to suit their particular discipline.

CPBL is described by Oliver (2001) as an approach that challenges students to construct their own knowledge and understanding within a team environment and in the context of a genuine problem. He defines CPBL as engaging students in "the process of designing and creating products that meet authentic needs" (Oliver, 2001, p. 7). The teacher's role is altered from that adopted in more traditional approaches as it becomes that of a facilitator or moderator (Ljoså, 1998). A number of commentators point out that interactive, collaborative learners can be well-supported in a web-based environment and remark that asynchronous online communication encourages significant peer interaction to take place (Roberts, 1995, Oliver, 2001, Gagné et al. 2005). Thus, when an eLearning approach is being used, it can readily facilitate the application of CPBL as a teaching and learning strategy. The benefits of using online group projects as assessment method are emphasised by Chickering and Ehrmann (1996) who point out that they incorporate several of their Seven Principles of Good 
Practice in Undergraduate Education including active learning, student-student interaction and time on task. They also report that it is often observed that learners perform to higher levels when they are aware that other students will be able to view their assignments and correspondence on the web. Our group found this to be the case and, at times, because we were very absorbed with the collaborative group assignment, it led to some problems with finding time to work on our individual paper. As with any approach that involves online communication, it is very important to ensure the provision of clear guidelines on acceptable social interaction online, often referred to as 'netiquette' (Beetham, 2002).

CPBL is based on a social constructivist approach and McMahon (1997) remarks that effective web-based interactive and authentic learning can be designed based on social constructivist principles. In addition, Paloff and Pratt (2005) regard collaboration as a "hallmark of constructivist learning theory" (p. 6). The social constructivist theory of learning, which originated with Vygotsky, recognises that learning occurs in specific social contexts (Beetham, 2002). The theory claims that active learning occurs and that it that centres on social interaction and shared tasks in which individuals build their learning by interacting with the environment, particularly teachers and fellow students. Collaboration on meaningful and challenging activity-based programmes promotes exploratory learning and is regarded as a highly effective means of encouraging learning (Bigge and Shermis, 2004). The benefit of this approach is that learners can capitalise on their strengths and overcome their weaknesses while working on a collaborative task. Students also encounter alternative methods adopted by other learners. Portimojarvi (online communication, February 13, 2006) sums up this approach as viewing "students as subjects of learning, not objects of teaching". McMahon (1997) discusses the criticisms of social constructivism, particularly that the strategies developed to deal with a problem are often not efficient and that there can be a lack of recognition that there is a certain "body of undisputed knowledge" in any subject (p. 6).

Paloff and Pratt (2005) examine how problems associated with collaborative approaches may be accentuated in online groups. The major difficulties they identify are:

- participation, ranging from dropout through to under-participation to domination in groups and includes issues such as lack of communication, reluctance to share findings and over-expectation. The outcome of these issues may lead to mistrust, resentment and conflict;

- leadership and decision making raises issues such as ineffective and aimless leadership, formation of powerful cliques, excluding less assertive members from decision-making and under-representation of particular viewpoints (gender issues, for example);

- course and activity design, particularly in relation to time issues, technical support and academic staff issues;

- although online learning tends to be more inclusive, cultural issues may still be identified.

McConnell (2005) conducted an ethnographic study on the work of three online groups and provides detailed analysis of their online discussions. He describes issues that arose in relation to reactions by group members to delayed responses to messages, the detrimental impact of levels of anxiety among individuals on group 
performance, the influence of strong personalities and the negative and positive effects of tutor interventions.

\section{Reflection}

The other assessed component of the module involved writing an individual paper based on completion of an online reflective journal. Moon (1999) comments that reflection:

"is applied in many fields and as a concept it helps those in learning and professional situations to make sense of an area of human functioning" (p. 91).

Beetham (2002) advises that online learners be given the opportunity to carry out selfassessment through the use of online logs or diaries.

To support and facilitate reflections by the module participants, our module tutor provided prompts each week in which she highlighted the relevance of assignments to eLearning issues and our development as eLearners (for example, considering the differences between online and face-to-face communication and how best to deal with learners who are not contributing online). These prompts were very helpful for structuring our reflections and ensuring that we were thinking about online learning at a deep level. Cowan (1998) also recommends this strategy and says that, instead of just being asked to reflect, that learners should be presented with carefully considered questions that they will find useful to answer.

Online Interactive Activities (e-tivities)

In addition to the CPBL and reflective paper assignments, our tutor designed a series of e-tivities for formative assessment on a weekly basis. The initial online tasks set were designed to acquaint us with the online supports and resources available and to ensure that we could post and reply to discussion board messages and create our own web page. The e-tivities were scaffolded and became more involved as the weeks passed and most of them involved online collaboration. In some cases, the reflective prompts for the individual paper were linked to the task assigned that week. These activities ensured that we were engaged in active learning throughout the module. The approach that we experienced as eLearners is described by Salmon (2002) in her five stage model.

\section{OUR E-LEARNING EXPERIENCE}

In this section of the chapter, we discuss the main issues that arose during our eLearning experience from a student perspective and include the relevant implications from the perspective of teachers and course designers.

\section{Support and Resources}

Salmon (2000) emphasises that learner support from an experienced tutor is essential to ensure that positive and productive eLearning occurs. At our induction session, it was clear to us that we were coming to the module from very different starting points and the novice eLearners found the learning curve very steep. We had many teething problems and the experience was a valuable insight into the emotions and frustrations that students feel when a lack of familiarity with technology prevents them from participating or keeping up. Our tutor anticipated the potential difficulties ahead and recommended a peer mentoring system within the group. This was taken up by two novice participants and was found to be very helpful. This combination of tutor and 
peer support, together with paired activities that were assigned, helped the less experienced members to cope with the demands of working online.

The importance of a vigilant and good humoured tutor as a positive role model was a particularly valuable lesson. She demonstrated best practice in challenging and supporting each student according to their level and experience. Our own eLearning experience, therefore, upholds the contention that blended learning can cater for individual learning needs. This brought it home to us that eLearning was not just about the technology and it became apparent that technology complements rather than replaces the human dimension of learning. Our experience also supports the assertion by Gagné et al. (2005) that the effort, skill, and pedagogy of the teacher is the most important factor influencing the success of an online course. Page and Donovan (2005) concur with this stating that "the contribution of the teaching practitioner is vital" (p. 28).

The equipment required to participate in a range of activities (asynchronous discussion, online chat, video conferences etc.) was available as was technological support to provide assistance. Our eTutor was ever present in a combination of faceto-face and online interaction throughout the ten week module. We were encouraged to access the Frequently Asked Questions section of the VLE developed for the module or to ask our peers before contacting the tutor directly with a problem. This developed our independence and strengthened the group dynamic and meant that the tutor's time was not being absorbed by minor issues.

\section{The Group Process}

Our group tackled the various tasks at a series of CPBL tutorials held every week. At each tutorial, a different group member acted as the 'chair'. As a blended approach was being used, two of these tutorials were held online and the remainder were faceto-face. Once the group had experienced the first online chat in week four, extra chats were often scheduled midway through the week to allow progress on the project to be communicated. Thus, we recognised the value of being able to 'meet' online as a group in between our face-to-face contact. The tutor structured our module so that we were required to give a work in progress presentation on our CPBL project in week five and this ensured that we focused on the task in hand.

In blended learning, personal contact between teachers and learners and among learners themselves is reduced. Significant efforts are needed to develop social relationships through discussions, chat rooms and virtual meetings (Gagné et al. 2005). Our group did not suffer from this problem as we already knew each other and we also met face-to-face weekly or fortnightly and organised 'extraordinary' meetings to progress our group project. Face-to-face meetings were identified as critical to the success of our project and certain members suggested they would have dropped out without this face-to-face contact and peer support.

As our group members already knew each other and we had participated in some collaborative projects with other students as part of previous modules on our Third Level Learning and Teaching programme, many of the difficulties that can arise in collaborative work were not serious issues for us. Our tutor maintained an involvement in our initial face-to-face and online group tutorials in case any significant problems arose and to provide clarification on the assessment requirements. Her suggestion to agree ground rules for the group which included a system of having a rotating 'chair' as well as a 'scribe' (to record ideas and act on 
items) each week helped to ensure that we usually worked effectively.

The usual issues of some participants initially 'lurking' online and frustration over delayed responses to postings arose (Salmon, 2002) and they were discussed among the group and reflected on with the encouragement of some tutor prompts quite early on in the module. One of the main problems we encountered during the Designing eLearning module was time management. All group members reported that they found participating in the module very intense and that a lot of other aspects of their lives had been 'put on hold'. While it was felt that the assessments and each e-tivity were worthwhile and contributed to our learning, they demanded a significant time commitment. Meeting deadlines and appointments for synchronous discussions made us acutely aware of the many pressures of group learning and, on occasions, led to anxieties within the group. It is worth highlighting that all participants on our module were part time students and thus time management will always be expected to be an issue. Interestingly, though, Concannon (2005) identifies the issue of 'full time part time students' as a recent phenomenon in higher education institutions. These learners are enrolled on full time courses but also spend significant amounts of their time working in part time jobs.

Hiltz and Goldman (2005) suggest that students spend more time on collaborative online courses than traditional courses. Students find it more demanding because they must actively participate in the group work, rather than passively taking notes. Some learners have expressed concern over the time required to post considered responses to a discussion board (Sweeney, O'Donoghue \& Whitehead, 2004). Course designers may also fail to allow students adequate time to complete online course activities causing considerable anxiety. Competing demands of individual modules may create significant pressure and disrupt students' personal lives which can be demotivating.

The group also found it difficult to decide whether participants should work on CPBL project tasks that involved skills and knowledge they already had or that they lacked the former being more likely to lead to a better group outcome and the latter allowing more learning to occur.

Accessibility

Salmon (2000) has noted that students using online learning for the first time often have serious difficulties gaining initial access. Our group had some previous experience of using a VLE as students on the Postgraduate Certificate in Third Level Learning and Teaching where we used it to access notes and announcements and, in some cases, for email and some discussions. Despite our previous experience of WebCT and the technical support provided, some of us experienced significant difficulties. Some participants were on a dial up connection at home and this caused problems such as tying up family phone lines and being disconnected during the synchronous chats leaving the participant with gaps in the thread of the discussion. One group member did not have an internet connection at home and had to travel to a relative's house to have access outside working hours. Another participant could usually only access the internet late at night and was often cut off without warning when using the discussion board in the early morning while the system was being backed up. Also, a member of the group was an Apple Mac user and experienced navigation problems that did not make any sense to the rest of the participants. In the first synchronous chat session, a group member inadvertently selected an option that prevented the others from seeing the contributions that she was typing. 
Online approaches are not likely to be suitable for those with internet access problems. As many families only have a single connection, competition for line time can be intense and the cost of access may also be an issue. Gagné et al. (2005) remark that slow connection and long download times are frustrating and make participants impatient, angry, or even give up. Paloff and Pratt (2005) regard the inability to access the course or contact peers as the worst thing that can happen to an online student. Our experience supports this finding as a significant amount of the online communication over the first half of the module included accounts of problems that had occurred and requests for information and hints on how to perform tasks using the technology.

The fact that this module was blended and used a combination of online and face-toface contact was very beneficial to participants struggling with the technology. For some people, it was such a roller coaster of new experiences and terminology that the face-to-face sessions were reassuring and provided an opportunity to discuss their problems. At all times, we were aware of the support from the institution, the extensive range of Frequently Asked Questions in the VLE, our ever vigilant tutor, and the bank of knowledge and goodwill coming from the group itself.

\section{Online Communication}

Hiltz and Goldman (2005) describe the potential of asynchronous discussion as the greatest benefit offered by online learning. Classes may be spread out in space and time in what they refer to as "a rolling present" (p. 6). Students contribute at their own pace, times and places that are most convenient for them. The group quickly identified the flexibility of using online synchronous and asynchronous communication as a particular strength of the blended approach. Participants were occasionally away from work or abroad but were able to keep in touch and play a part in the group activities. Contributions were made from Denmark, Italy, Spain and the United Kingdom as well as locations throughout Ireland. Discussions with online guest tutors from the University of Tampere in Finland and the University of Queensland, Australia took place during the module. These tutors added an international dimension and provided fresh perspectives and their contributions would only have been possible in an online situation.

We also discovered that online communication is very different to face-to-face. Smith (2001) observes that face-to-face discussion is essentially linear; one conversation is dealt with at a time. Online discussions, however, may involve a number of simultaneous discussions and Swan and Shea (2005) describe them as growing "like crystals from multiple conceptual seeds in many dimensions at once" (p. 247). We also quickly realised that discussion online can be unstructured. We set up too many discussion threads and this led to messages being posted to the wrong place and getting 'lost'. This was confusing and resulted in a needlessly 'packed' and disorganised discussion board. One participant remarked that the amount of messages being posted was overwhelming and that they were finding it difficult to cope. Another group member frequently did not open attachments because of a connection with a slow downloading speed.

As discussion boards provide a record of all online communication within a group, contributors can review, link to and build on various strands. Discussions and a learning environment that were rich and reflective developed as a result of this facility to review and build on previous postings. Salmon (2000) notes that many postings are actually composed offline which shows that learners are taking the time to construct 
their ideas and thoughts. We found that the discussion boards, chat rooms and email facilities helped the Group to 'gel' and work in a committed and collaborative manner (Roberts (1995), Oliver, (2001), Gagné et al. 2005). This collaboration was essential in achieving the module aims efficiently and completing our group assignment. Although some of us had used discussion boards before, the level of interaction and the eModerating skills demonstrated by our tutor (e.g. summarising and weaving of contributions, posing relevant questions) was a new aspect and allowed us to observe and experience good practice at first hand.

The group was also introduced to a wider range of eLearning methods, particularly the use of the chat facility. This was new to most of us as very few had any experience of synchronous online communication within a VLE or indeed any of the proprietary chat rooms. Our tutor introduced us to our first chat and facilitated the session and after that our chats were organised and facilitated by a 'chair'. The chair position rotated among all group members from week to week. The chats were summarised by the chair and posted on the discussion board for the benefit of any participant who missed the session and also to provide a record of the issues discussed.

In addition, two guest tutors used MP3 format to record their responses to our discussion board postings as audio files. This was a completely new experience for all and several of the group felt that they could relate to the tutors online more easily having heard their voices.

We also had a video conference session with a guest tutor in Finland. This was a fascinating experience as we could see and hear the guest tutor. As it happened, technical difficulties arose as the sound broke down from our end so initially we could hear the tutor but he could not hear us. This illustrates the need to anticipate likely technical problems and to plan how they will be dealt with. As a result, the group suggested to the Technical Support Team that a central log listing technical difficulties that have been encountered and the steps that were taken to solve or get around them be established.

The depth of discussion that is possible using asynchronous online discussion is very impressive but, with students who have not encountered this approach before, it can be challenging for an eTutor to ensure that they participate effectively (Clouder \& Deepwell, 2004). Most students have been shown to be sophisticated technology users (Conole et al., 2006) and thus would be expected to appreciate the opportunity to communicate using asynchronous and synchronous online communication, audio files and video-conferencing to further their learning.

\section{Assessing Learning}

One of the most immediate priorities for any learner, of course, is to determine what they have to do to pass a particular module. Ramsden (1992) maintains that "the assessment IS the curriculum as far as the students are concerned" (p. 187) and Biggs (2003) recommends that assessments and learning activities are aligned with learning outcomes to ensure that effective learning and teaching occurs. Ross (1997:33) points out the danger of undermining the intended learning outcomes if inappropriate assessment strategies are applied and the difficulties associated with assessing groups. Therefore, it is important to examine how the module was assessed and how we experienced that assessment process. As already described, the module was assessed by a combination of a CPBL group assignment and an individual paper based on completion of an online reflective journal. The group were of the opinion that the pass 
/ fail assessment method applied was fundamental to the success of our learning. We found it liberating to be assessed on a criterion-referenced basis rather than normreferenced. We liked the clarity of the criteria and the associated pass / fail classification and those participants who were less confident when they began the module found this assessment approach particularly reassuring. In addition, this approach meant that competition among participants did not occur and it fostered a collaborative spirit.

We found that completing the CPBL assessment ensured that we met the module learning outcomes and we agreed that we were motivated to reach a higher standard than we would have if we had been working individually. Some felt though, that at times more patience and reflection from other members within the group was required, especially from those who were more familiar with a web-based learning environment and had ambitious ideas for the project assigned. One aspect of the assessment that several group members felt strongly about was that there was no group CPBL project presentation scheduled at the end of the module. A work-inprogress video conference presentation took place halfway through the module and the feedback received was very useful. At the end of the module, the group report was submitted and many of the participants said that they would have liked the opportunity to make another presentation at this stage.

The reflective paper prompted us to engage in the module. It ensured that each of us was thinking about what we were experiencing throughout. At the end of week five of our module, we were required to submit extracts from our reflective journal for formative feedback. Thus we received guidance and direction at an interim stage and this submission of work in progress ensured that we were engaged throughout the module. Concannon et al. (2005) have commented on the benefits of designing assessment strategies so that learners must work on a continuous basis, rather than allowing them the opportunity to put it off until the end of the module. In the case they describe, the introduction of computer aided assessment made this redesign possible. We found that the online reflective journal provided us with a record of the problems, concerns and rewards that we experienced as eLearners. It was also interesting that we noticed, that many of the effective eLearning practices we were researching and discussing as eLearning designers for the CPBL project, were implemented in the module design, and thus, we were experiencing them as learners. In particular, we gained insights into how to effectively support online learners and to provide a framework allowing for a progressive increase in complexity of assigned activities. Salmon (2002) emphasises the importance of both of these issues in providing effective online tutoring:

"For online learning to be successful and happy, participants need to be supported through a structured development process" (p. 10).

Thus, the individual reflective piece was an important component of the module assessment, as it ensured that we considered and discussed how it felt to experience blended eLearning, and that we recorded our thoughts and feelings at all stages of the module.

Both summative assessment strategies, the CPBL project and individual reflective paper, were found to be effective in ensuring that the module learning outcomes were achieved and would be recommended for inclusion in any blended course design. We would also recommend that a pass / fail criterion-referenced system be implemented as much as possible with undergraduate students, although it is recognised it is often a 
requirement that final year modules are assigned grades so that degree classification is possible.

\section{THE DUAL DESIGNER AND E-TUTOR PERSPECTIVE: DESIGNING AND DEVELOPING OUR OWN PRACTICE}

One of our central module learning aims was to develop an awareness of the important issues to consider when designing blended learning. We now examine the design and development of the module produced for our group CPBL project from the perspective of eDesigners and eTutors in addition to the student perspective already discussed.

We chose to design and produce a blended, activity-based six-week information literacy skills module for first year undergraduates called the Information Treasure Chest. Development of these skills is very important as the ability to find relevant information quickly and efficiently using the resources available is one of the key factors that allow lifelong and self-directed learning to occur (Sormunen, 2006). Initially, a series of interviews was carried out with staff in seven different libraries as part of a needs analysis to establish how best to make the proposed programme effective. One of the most important findings from this research was that the librarians all believed that their libraries were rarely used to their full potential, that the development of information literacy skills should be integrated into programme curricula and that credits should be available for any related assignments. Ambrose and Gillespie (2003) are among several authors who have made the case for integration of information literacy skills into curricula. Further research amongst academic and administrative staff and students was carried out as the module design was in progress.

The module aim and learning outcomes were derived from the needs analysis. The principal aim was to introduce students to library resources and to encourage the development of library research skills to enable them to make fuller use of library resources, both paper and electronic. The module also set out to build student awareness of the value of libraries in expanding, adapting and updating their personal knowledge base throughout the lifelong learning process.

The design philosophy was developed in tandem with the aims and objectives. Some of the key issues that shaped our module design were that;

- we wanted the learners to develop as reflective, critical thinking problem solvers

- we viewed the lecturer as a facilitator / tutor. Ramsden (1992) summed up this approach when he remarked that "the aim of teaching is simple: it is to make learning possible" (p. 5).

- the module would be activity-driven instead of content-driven. Laurillard (1993) contends that the acquisition of concepts is of no use if learners can't apply them and states that it is important to provide multiple contexts for a conception instead of an abstraction alone.

- the module activities would be integrated into each subject discipline to ensure learner motivation and to differentiate our module from some generic information literacy skills modules already available.

The philosophy underpinning our module design was informed by four learning theories; cognitive, constructivist, social constructivist and learner differences. Figure 
1 in Appendix 2 illustrates how technology is related to these theories in the module we developed.

\section{VLE and E-tivities}

A template for the exemplar virtual learning environment and several examples of online content and activities using WebCT software were developed. We designed the six week module for the first half of a semester with one hour of face-to-face teaching for some of the weeks. The module begins with a face-to-face induction session during which students are given the module handbook developed for the module. A workshop also takes place to teach them how to log on, navigate the VLE and use the discussion board. The first activity is contained in the library induction pack to ensure that they have to attend a library induction session to get this task.

From the eTutor perspective, the e-tivities developed were carefully structured to ensure that they were scaffolded. Thus, the tasks are progressive, increasing in complexity over the course of the module and they are designed to incorporate the five stage framework devised by Salmon (2002). Table 1 in Appendix 3 summarises these e-tivity tasks.

Our group had identified the ability to make course materials readily available as one of the reasons why we would adopt online learning approaches. However, there can be a temptation to adopt a 'shovelware' or 'electronic filing cabinet' approach. To avoid this, we ensured that consideration was given as to the effectiveness and educational validity of the materials incorporated into the VLE developed. Easy and flexible navigation of the resources was also a priority.

Bonk et al. (2004) make the point that it is the pedagogy used and the learning outcomes achieved that are important in a programme of study, not the type of technology involved. This was the approach taken in designing the Information Treasure Chest module and eLearning technology was employed where appropriate in such a way that its benefits were exploited.

\section{SOLUTIONS AND RECOMMENDATIONS - WHAT WE LEARNED FROM OUR EXPERIENCE AS E-LEARNERS}

The main issues that arose in relation to blended learning from the student, teacher and designer perspective are now summarised and relevant solutions and recommendations are included where appropriate.

Pivotal Role of the Tutor

It became very apparent to us that the tutor had an essential role in providing learner support, particularly at the beginning of a blended module. This requirement is welldocumented in the literature but our interaction with the tutor during the first few weeks of our module was so effective that we want to draw attention to this issue. As we gained confidence in our online interaction and developed our background knowledge, our tutor continued to facilitate our learning and to challenge us by providing progressively more difficult activities.

Module Design

We found the formative and summative assessment methods used to assess us to be appropriate and they had been designed carefully to ensure that the learning outcomes were achieved and that we were engaged with our learning throughout the module. 
One general conclusion from all participants was that 10 weeks was a very short time frame in which to complete the module and each of us reported problems with time management and related anxiety. As all of the learning activities and assessments were of value, the participants felt that 15 weeks would have been more appropriate. The duration of the module is, however, subject to timetable constraints and it is recognised that this change may not be feasible. If this is the case, perhaps some of the weekly online tasks could be reviewed and shortened. The participants felt that the criterion-referenced Pass / Fail classification used for the summative assessments was clear and fair to all and hope to incorporate it to a greater extent in their own teaching.

Another issue reported by the group was that most of the participants said that they would have liked the opportunity to give a presentation at the end of the module. An evaluation questionnaire was circulated when the module was complete allowing the students a means to communicate this suggestion to the module tutor. However, as McKeachie (1996) observes, "students are not the evaluators; they simply provide data to the evaluators" (p. 7). Thus, there may well be logistical issues that would make this change difficult to implement or it could be that there were sound pedagogical reasons for having a presentation at the halfway stage of the module and not also scheduling one at the end.

\section{Group Work Division}

Regarding the issue of whether participants should choose tasks relating to the CPBL project that involved skills and knowledge that they already had or that they lacked, the recommendation in the literature is that the major component of a CPBL project must not involve students applying skills that they already had (Thomas, 2000). The issue only arose in relation to one part of the project which was experience of using the software to produce the exemplar VLE. As it involved greater learning occurring, the group agreed that participants who did not have previous experience would work on the exemplar VLE, with the support of those who had.

\section{Tackling the Disadvantages and Barriers to eLearning}

It is important to have an awareness of the most common issues and problems that can arise when eLearning methods are introduced. In this way, many of the likely difficulties can be anticipated and systems put in place to deal with them if they occur. Several authors have produced useful recommendations and guidance in this regard (Salmon, 2000, Holmes \& Gardner, 2006 and Sharpe et al., 2006). As has already been discussed, the initial induction and access stage is particularly critical in online learning and requires careful planning and support. Other problem areas that have been highlighted in this chapter include the challenge of keeping students motivated and engaged, lack of online access and technical problems, anxiety over time management and the need to develop social interaction online. In addition, the difficulties encountered with collaborative group work will often apply but are not exclusive to eLearning.

Issues relating to the successful implementation of online learning in higher education institutions are examined in more detail towards the end of the following section on Future Trends. The barriers that are often encountered relate to the provision of the necessary support structures and development of a clear eLearning strategy at an institutional level. Holmes and Gardner (2006) emphasise that structures and resources need to be put in place to facilitate web-based learning innovations without excessive preparation and time commitments and Mason (2001) observes that 
methods of reducing the time demands on eTutors need to be found as 'interaction fatigue' can set in.

\section{FUTURE TRENDS}

Some of the relevant emerging and future trends in online learning in higher education will now be examined briefly. Potential impact on the learner experience will also be considered where appropriate.

An emerging trend of particular interest and relevance is online problem-based learning (PBL). There have been a number of recent developments in this area. SavinBaden (2006) emphasises that the aim of online PBL is to develop and supplement what has already been achieved rather than replace it. She uses the term 'blended PBL' to describe the type of approach used in the CPBL project that our group undertook.

Another development that our group feels is very significant for designing eLearning on the basis of our experience as eLearners is podcasting. Campbell (2005) explains that the term 'podcast' is derived from the words 'iPod' and 'broadcasting' and that this approach essentially involves making audio files available to download. Although we had limited experience with podcasting, we are all enthusiastic about its use in eLearning. Our guest tutors from Australia used this technology when they were interacting with our group. Our experience was that we felt we knew them much better as a result of hearing their voices and because of the descriptions they gave of where they were recording from. This humanisation of our interaction broke the ice and drew us in as we listened to our first podcast for educational purposes. Admittedly, there here may have been a 'novelty' factor at play to some extent but we found that the content of the guest tutor's audio file contributions were much more memorable than the written discussion threads that they posted. This impact is emphasised by Campbell (2005) in the following quote:

"Done well, podcasting can reveal to students, faculty, staff, communities - even the world - the essential humanity at the heart of higher education" (p. 44).

Holmes and Gardner (2006) have remarked on the potential of recording feedback when assessing work and posting the audio file to the student immediately afterwards. However, they identify that there are problems associated with this rapid feedback approach if comments that have not been thought through fully are made.

Another significant emerging trend is e-Portfolios. Each member of our group had already completed a teaching portfolio and thus we were interested in the possibility of completing an e-Portfolio. This can included podcasts, emails, discussion threads, blogs and journals. Jafari (2004) has examined the advantages of and difficulties in implementing e-Portfolios in higher education.

We are also conscious that there is a wider community of practitioners and academics who are willing to share online resources. In Ireland, the National Digital Learning Repository (NDLR) has recently been launched. Many other countries have developed similar repositories.

Mobile learning or m-learning is another emerging trend. While participating in the Designing eLearning module, group members occasionally used mobile phone communication. At present, most institutions have a texting software package to keep students up to date with announcements such as exam deadlines and cancelled lectures and Conole et al. (2006) have found that students use mobile phones 
extensively to communicate with peers and tutors. In a recent presentation, Sharples (2007) described an example of recent good practice, the MyArtSpace project, in which multimedia mobile phones were supplied to second level students when they arrived at a museum. They were given several tasks to perform that required them to interact with the exhibits. These included taking photographs and video clips and collecting other relevant material which they then edited back at their schools to produce an online gallery. It was found that the students spent significantly more time interacting with the exhibits and gathering information when this approach was used compared to the traditional visit format.

There are several features usually available within a VLE that our group did not have time to explore such as quizzes and animations and making grades available to students. Thus, in addition to investigating future and emerging trends, it is also a priority to us to consolidate our knowledge and experience of the current VLE systems available and to become confident in practicing the eLearning and teaching that we have experienced first-hand before we extend into new areas.

Institutional Support

It is important to mention issues relating to implementation of effective online learning and teaching at third level and the context of the strategy and culture within an individual institution. One participant in our group commented that:

"Before I began the module, I was very hesitant about getting involved in eLearning because of a lack of relevant knowledge and skills. Having completed the module, I am still holding back, but now it's because I'm aware of the significant amount of preparation and learner support that must be provided to implement meaningful eLearning in a way that makes use of the added value it can provide."(Participant B, March 2007)

Mason (2001) describes the approach taken by the Open University to incorporating online learning into their distance education courses. A clear policy decision was formulated not to "put all courses online" (p. 70) as it was felt it was a waste of resources to place a great deal of text online when students were going to print it out to read it more easily anyway. Instead, the institution focussed on developing features such as online tutoring and conferencing as well as collaborative small group activities. A clear and informed institution-wide strategy was obviously important in supporting staff as they developed online learning in this particular case. In other third level institutions, the adoption and implementation of eLearning has not always been considered to the same extent. Donnelly and O'Rourke (2007) warn of the danger that adoption of online learning may be performed superficially by third level institutions if the yardstick used is the quantity instead of the quality of the learning. They also emphasise the need for professional development of academic staff in the area of eLearning coupled with ongoing support from experts and peers. Butler and Sellbom (2002) report that they identified three main barriers to adoption of Internet and Web technology. They are a lack of financial support, lack of institutional support and a lack of time to learn new technologies.

\section{CONCLUSION}

Our group of online learners found that our lived experience as eLearners participating in a carefully constructed, blended, activity-based course was invaluable to our academic development as eTutors and module designers. We gained insights 
into the common problems and challenges that students encounter as well as the benefits and potential difficulties associated with eLearning. We would strongly recommend this approach for learning how to be an effective online tutor and facilitator and how to design and develop online programmes and activities that make full use of the strengths of online learning. As one of the participants in our group commented:

"it makes it much easier to teach using these methods having experienced them as a student." (Participant D, April 2006)

Several difficulties associated with online learning were encountered and these are important issues for teachers and designers to consider when implementing blended learning. It is vital that the necessary support is available during the induction phase, which Salmon (2000) refers to as the access and motivation stage. The tutor has a very important role at this point in welcoming and encouraging students and making the benefits of web-based learning apparent as well as demonstrating good practice in their online communication. Sufficient technical support is essential to ensure that participants can access the ICT systems quickly and easily and that any initial problems are dealt with efficiently. The fact that our group consisted of people with varying levels of prior experience meant that we became aware of the range and extent of initial learner support and motivation required and the role that peer mentoring can play. Other issues identified that can be problematic for eLearners include access to the Internet, time management and a lack of social contact. As eLearning often involves collaborative group work, the difficulties associated with group work such as under-participation and ineffective communication and decisionmaking may also arise. It is important that facilitators are aware of these problems so that they can identify them quickly and take steps to remedy them.

Issues relating to the type of formative and summative assessments used were examined. Our group found that the CPBL project, individual reflective piece and etivities employed had been aligned effectively with the learning outcomes and were valuable to our learning. Thus, from both a learner and course designer perspective, these type of assessments were appropriate and suitable for blended learning. The issue of careful planning to allow adequate time for learners to complete assignments is important and, in our case, we would have preferred a longer timeframe for the module if that were possible. We also found that the criterion based pass / fail classification used was clear to all and fostered a collaborative spirit. It is important when designing online assessments to ensure that students are active and motivated throughout the duration of the module by incorporating regular activities and milestones, as was the case in the module we experienced.

The design and development of the online information literacy module for our CPBL assessment allowed us to develop and apply important skills and knowledge and to experience the role of eDesigner. Important considerations that shaped our course design included: provision of effective learner support at the beginning of the module, scaffolding of the designed e-tivities and applying the activities to the relevant subject discipline to provide a relevant context. Also, eLearning technology was only incorporated where appropriate and where it was felt it would genuinely be of benefit to the learners. There is a genuine need for the information literacy skills module we produced and it has been implemented by one participant already and will be adapted and used by several others in the group in the coming year.

We are aware of the relevant emerging trends in web-based learning which include 
online PBL, podcasting and m-learning. These are exciting developments, but our group feel it is important to consolidate what we have already learnt and apply it in our teaching, before we try to incorporate emerging trends to any significant extent.

Some issues relating to implementation of effective eLearning in Higher Education Institutions were also considered. Important requirements are: institutional and financial support, sufficient time allocation, appropriate professional development courses for academic staff to learn new technologies and ongoing support from experts and peers.

\section{FUTURE RESEARCH DIRECTIONS}

At present, we are concentrating on applying the skills, knowledge and insights developed in the Designing eLearning module. For some of us, this involves adapting and using the information literacy skills module that we developed, while others are incorporating greater interactivity and collaborative work into existing web-based aspects of our courses.

We hope that these developments will provide the basis for a future publication, as we intend to assess the extent to which each participant on the module applied the knowledge and skills developed. We will also review the enablers and barriers we encountered to implementing web-based learning. As discussed earlier, several factors critical to the successful introduction of eLearning have been identified in the literature (Donnelly \& O'Rourke, 2007, Butler \& Sellbom, 2002). We plan to compare their findings with ours. We also intend to evaluate the attitudes and opinions of our students and academic colleagues to the changes implemented to gain insights into their perspectives on blended learning. We would also like to examine the quality of the learning achieved when the new web-based strategies are implemented.

In addition, we would like to examine what is meant by eLearning at an institutional level. If it is perceived that information repository and course management aspects are all that are involved, then there is little incentive to develop interactive activities (individual and/or collaborative) or promote meaningful online discussion. Another potential future research topic is the professional development of academic staff in the area of pedagogy and technology. We would be particularly interested in comparing the experience we had on the Designing eLearning module with other approaches described in the literature. Further aspects we would like to study are the contribution that peer-tutoring can make (Reilly, 2005) and the most effective strategies for ongoing support for academic staff who are actively involved in online learning.

\section{REFERENCES}

Ambrose, A., \& Gillespie, B. (2003). Information-literacy programmes and programme curricula: the case for integration. Level 3, 1. Retrieved February 18, 2006, from http://level3.dit.ie/html/issue1_ambrose1.html

Arbaugh, J. B. (2004). Learning to learn online: A study of perceptual changes between multiple online course experiences. Internet and Higher Education, 7, 169182.

Beetham, H. (2002). Understanding eLearning, e-Tutoring for effective eLearning resources. Higher Education Academy. Retrieved April 3, 2007, from

http://www.ics.heacademy.ac.uk/events/displayevent.php?id=22 
Beetham, H. (2005). E-learning research: emerging issues? ALT-J, Research in Learning Technology, 13(1), 81-89.

Bigge, M. L., \& Shermis, S. S. (2004). Learning theories for teachers (6th ed.). Boston: Pearson.

Biggs, J. (2003). Teaching for quality learning at university (2nd ed.). Buckingham: Open University Press.

Bonk, C. J., Kim, K., \& Zeng, T. (2004). Future directions of blended learning in higher education and workplace learning setting. Chapter to appear in Handbook of Blended Learning: Global Perspectives. San Francisco: Pfeiffer Publishing. Retrieved 24 March, 2006, from http://www.publicationshare.com/c083_bonk_future.pdf

Butler, D., \& Sellbom, M. (2002). Barriers for adopting technology for teaching and learning. Educause Quarterly, 25(2) 22-28. Retrieved May 25, 2007, from http://www.educause.edu/ir/library/pdf/eqm0223.pdf

Campbell, G. (2005). There's something in the air: podcasting in education. EDUCAUSE Review, 40(6), 32-47. Retrieved 16 May, 2007, from

http://www.educause.edu/apps/er/erm05/erm056.asp

Charlesworth, P., \& Vician, C. (2003). Leveraging technology for chemical sciences education: an early assessment of webCT usage in first-year chemistry courses. Journal of Chemical Education, 80(11), 1333-7.

Chickering, A., \& Ehrmann, S. (1996). Implementing the seven principles: technology as lever. American Association for Higher Education Bulletin, October, 3-6. Retrieved February 24, 2006, from http://www.tltgroup.org/programs/seven.html

Clouder, L., \& Deepwell, F. (2004). Reflections on unexpected outcomes: Learning from student collaboration in an online discussion forum. Paper presented at the Networked Learning Conference, Lancaster University, England. Retrieved August 20 , 2007 , from http://www.networkedlearningconference.org.uk/past/nlc2004/proceedings/individual _papers/clouderanddeepwell.htm

Conole, G., de Laat, M., \& Dillon, T., \& Darby, J. (2006, December). An in-depth case study of students' experiences of e-Learning - how is learning changing? Paper presented at the Australian Society for Computers in Learning and in Tertiary Education conference, University of Sydney, Australia. Retrieved August 8, 2007, from

http://www.ascilite.org.au/conferences/sydney06/proceeding/pdf_papers/p127.pdf

Concannon, F., Flynn, A., \& Campbell, M. (2005). What campus-based students think about the quality and benefits of e-learning. British Journal of Educational Technology, 36(3), 501-512.

Cowan, J. (1998). On becoming an innovative university teacher. Buckingham: Open University Press.

Donnelly, R., \& O'Rourke, K. (2007). What now? Evaluating eLearning CPD practice in Irish third-level education. Journal of Further and Higher Education, 31(1), 31-40.

Driscoll, M. (2002). Blended learning: let's get beyond the hype. Learning and Training Innovations Newsline. Retrieved August 7, 2007, from http://elearningmag.com/ltimagazine/article/articleDetail.jsp?id=11755 
Gagné, R. M., Wager, W. W., \& Golas, K. C. \& Keller, J. M. (2005). Principles of instructional design (5th ed.). Belmont, CA: Thomson Wadsworth.

Hiltz, S. R., \& Goldman, R. (2005). Learning together online: research on asynchronous learning networks. London: Lawrence Erlbaum.

Holmes, B., \& Gardner, J. (2006). e-Learning concepts and practice. London: Sage Publications.

Intute Virtual Training Suite website. (2006). Retrieved February 14, 2006, from http://www.vts.rdn.ac.uk/

Jafari, A. (2004). The "sticky" ePortfolio system: tackling challenges and identifying attributes. EDUCAUSE Review, 39(4), 38-48. Retrieved 16 May, 2007, from http://www.educause.edu/apps/er/erm05/erm056.asp

Laurillard, D. (1993). Rethinking University Education. London: Routledge.

Ljoså, E. (1998). The role of university teachers in a digital era. European Journal of Open, Distance and ELearning. Retrieved May 5, 2007, from http://www.eurodl.org/materials/contrib/1998/eden98/Ljosa.html

Mason, R. (2001). The Open University experience. In J. Stephenson. (Ed.), Teaching and Learning Online: Pedagogies for New Technologies (pp. 67-75). London: Kogan Page.

Matheos, K., Daniel, K., \& McCalla, G.I. (2005). Dimensions for blended learning technology: learners' perspectives. Journal of Learning Design, 1(1), 56-76. Retrieved August 10, 2007, from

https://olt.qut.edu.au/udf/jld/index.cfm?fa=displayPage\&rNum=1780740

McConnell, D. (2005). Examining the dynamics of networked e-learning groups and communities. Studies in Higher Education, 30(1), 25-42.

McKeachie, W. (1996). The professional evaluation of teaching. American Council of Learned Societies, Occasional Paper No. 33. Retrieved May 14, 2007, from http://www.acls.org/op33.htm\#McKeachie

McMahon, M. (1997, December). Social constructivism and the World Wide Web-a paradigm for learning, paper presented at the Australian Society for Computers in Learning and in Tertiary Education conference, Perth, Australia. Retrieved May 2, 2007 , from http://www.ascilite.org.au/conferences/perth97/papers/Mcmahon/Mcmahon.html

Moon J (1999). Reflection in learning and professional development. London: Kogan Page.

Morris, L. (2007, August). Pick and mix - getting the blend right. Paper presented at the Annual Variety in Chemistry Education Conference. Leicester University, UK.

Munro, M., \& Walsh, E. (2005, May). Online tutors as online students: preparing tutors to teach online. Paper presented at the Sixth Annual Irish Educational Technology Users' Conference, Dun Laoghaire Institute of Art, Design and Technology, Dublin. Retrieved March 2, 2006, from http://ilta.learnonline.ie/course/view.php?id=18

Oliver, M., \& Trigwell, K. (2005). Can 'blended learning' be redeemed? E-learning, 2(1), 17-26. 
Oliver, R. (2001). Developing online learning environments that support knowledge construction. In S. Stoney \& J. Burns (Eds.), Working for Excellence in the e-conomy (pp.407-416), Churchlands Australia: we-B centre. Retrieved April 10, 2007, from http://elrond.scam.ecu.edu.au/oliver/2001/webepaper.pdf

Page, A., \& Donovan K. (2005). Elearning a workbook for adult community learning. Leicester: National Institute of Adult Continuing Education.

Palloff, R. M., \& Pratt, K. (2005). Collaborating online: learning together in community. San Francisco: Jossey-Bass.

Quinney, A. (2005). 'Placements online': student experiences of a website to support learning in practice settings. Social Work Education, 24(4), 439-450.

Ramsden, P. (1992). Learning to teach in higher education. London: Routledge.

Reilly, C. (2005). Teaching by example: a case for peer workshops about pedagogy and technology. Innovate, 1(3). Retrieved May 22, 2007, from

http://www.innovateonline.info/index.php?view=article \&id=15

Roberts, L. (1995). A template for converting classrooms to distributed, asynchronous courses. Retrieved February 4, 2006, from

http://ww.unc.edu/cit/iat-archive/publications/roberts/template.html

Ross, B. (1997). Towards a framework for problem-based curricula. In D. Boud, \& G. Feletti (Eds.), The challenge of problem based learning (pp. 28-35). London: Kogan Page.

Salmon, G. (2000). E-moderating: the key to teaching and learning online. London: Routledge Falmer.

Salmon, G. (2002). E-tvities - the Key to Active Online Learning. London: Routledge Falmer.

Savin-Baden, M. (2006). The challenge of using problem-based learning online. In M. Savin-Baden, \& K. Wilkie (Eds.), Problem-Based Learning Online (pp. 3-13). Berkshire: Open University Press.

Sharpe, R., \& Benfield, G. (2005). The student experience of e-learning in Higher education: a review of the literature. Brookes eJournal of Learning and Teaching, 1(3). Retrieved August 15, 2007, from

http://www.brookes.ac.uk/publications/bejlt/volumelissue3/academic/sharpe_benfield .html

Sharpe, R, Benfield, G., Roberts, G., \& Francis, R. (2006). The undergraduate experience of blended e-learning: a review of UK literature and practice. York, UK: The Higher Education Academy. Retrieved August 20, 2007, from

http://www.heacademy.ac.uk/assets/York/documents/ourwork/research/literature_revi ews/blended_elearning_full_review.pdf

Sharples, M. (2007, May). Big issues in mobile learning. Paper presented at the Eighth Annual Irish Educational Technology Users' Conference, Dublin Institute of Technology, Ireland.

Smith, B. (2001). Teaching online: new or transferable skills? Higher Education Academy resource. Retrieved 21 March, 2006, from

http://www.heacademy.ac.uk/resources.asp?process=full_record\&section=generic\&id $=455$ 
Smith, T. (2005). Fifty one competencies for online instruction. The Journal of Educators Online, 2(2). Retrieved 21 December, 2006, from http://its.fvtc.edu/langan/BB6/Online\%20Instructor\%20Competencies.pdf

Sormunen, E. (2006). Web searching, information literacy and learning - Web-SeaL, Research Plan. Retrieved February 15, 2006, from http://www.info.uta.fi/tutkimus/WebSeal/Research_plan.pdf

Stracke, E. (2007). A road to understanding: A qualitative study into why learners drop out of a blended language learning environment. ReCALL, 19, 57-78.

Swan, K., \& Shea, P. (2005). The development of virtual learning communities. In S.R. Hiltz \& R Goldman (Eds.), Learning together online: research on asynchronous learning networks (pp. 239-260). London: Lawrence Erlbaum.

Sweeney, J., O'Donoghue, T., \& Whitehead, C. (2004). Traditional face to face and web-based tutorials: A study of university students' perspectives on the roles of tutorial participants. Teaching in Higher Education, 9(3), 311-323.

Thomas, J. (2000). A review of research on project based learning. Retrieved May 21, 2007, from http://www.bie.org/files/researchreviewPBL.pdf

Whitelock, D., \& Jelfs, A. (2003). Editorial: Educational Media Special Issue on Blended Learning. Journal of Educational Media, 28(2-3), 99-100.

\section{ADDITIONAL READING}

Alexander, S., \& Golja, T. (2007). Using students' experiences to derive quality in an e-Learning system: an insitution's perspective. Educational Technology and Society, 10(2), 17-33.

This paper examines the application of a systems approach to investigate how online learning is experienced by learners and teaching staff at an Australian college. The authors conclude that the students' perspective provides valuable data that will help to inform future developments in their institution. A useful review of existing guidelines on quality in eLearning is included and a comprehensive analysis of the students' views on online learning is provided.

Baker, J. D., Redfield, K. L., \& Tonkin, S. (2006). Collaborative coaching and networking for online instructors. Online Journal of Distance Learning Administration, 9(4). Retrieved April 12, 2007, from

http://www.westga.edu/ distance/ojdla/winter94/baker94.htm

This paper discusses an approach to academic staff development that applies collaborative coaching to train staff in becoming effective online tutors and instructors. A model has been developed which entails three phases (planning conference, instructional observation and reflecting conference). A collaborative coaching check list is provided based on the experiences of the authors over the past ten years.

Beetham, H., \& Sharpe, R. (Eds.). (2007). Rethinking pedagogy for a digital age: designing and delivering elearning. London: Routledge.

This book examines perspectives on the effective design and delivery of eLearning activities informed by pedagogy. Case studies are used very effectively to provide guidance, advice and practical examples. The discussion of relevant design issues and considerations on the use of eLearning activities are also very helpful. 
Boud D., \& Felletti G. E. (Eds.). (1997). The challenge of problem-based learning (2nd ed.). London: Kogan Page.

This book highlights the significance, uses, strengths and limitations of the problem based learning approach. The contributions are drawn from a wide range of disciplines based in many different countries. The analysis of issues relating to collaboration and assessment of group work is particularly useful.

Collison, G., Elbaum, B., Haavind, S., \& Tinker, R. (Eds.). (2000). Facilitating online learning: effective strategies for moderators. Madison, WI: Atwood Publishing.

This book is aimed at novice online learning facilitators. The focus is on practice supported by a balanced theoretical framework. Effective guidance and practical advice on how moderators can effectively facilitate online dialogue among learners is provided.

Conole, G., \& Oliver, M. (2007). (Eds.). Contemporary perspectives in elearning research: themes, methods and impact on practice. New York: Routledge.

In this text, the important debates related to eLearning and the emerging research findings are critically discussed by a number of experienced researchers. Among the areas addressed are socio-cultural aspects and the impact of policy and funding as well as more practical issues such as using tools and resources and e-assessment. A thorough understanding of the important themes that have developed in research on eLearning can thus be gained.

Cottrell, S. (2001). Teaching study skills and supporting learning. Basingstoke: Palgrave.

This text is based on the author's extensive experience of supporting learners in higher education. Examples and case studies on topics such as learner types, time management and developing critical analysis and group interaction skills are provided. The second part of the book contains a series of worksheets developed by the author. Although not designed for use in an online environment, many of these could be modified to become e-tivities without too much difficulty.

Cunningham, I., Dawes, G. \& Bennett, B. (2004). The handbook of work based learning. Aldershot, UK: Gower.

This book provides an overview of strategies, tactics and methods adopted to support work-based learning. The sections on networks and communities, e-learning and computer based training will be of interest to online facilitators. Each section contains a description of the process, provides examples, explains the benefits and limitations of the approach and gives guidelines and hints for those about to apply it.

Field, J. (2003). Social capital in a post (modern) world. In Social capital (pp. 91 114). London: Routledge.

In this chapter, research on the effect of online interaction on social capital is examined and discussed. The author concludes that social capital does not seem to be impinged on and that the Internet actually seems to be complementing it as it allows people to extend existing networks and build upon face-to-face connections.

Fox, S., \& Mc Keogh, K. (2003). Can eLearning promote higher order learning without tutor overload? Open Learning, 18(2), 121-134.

The authors address the very significant issue of whether an online environment requires a greater time input from facilitators. Selected teaching methods (peertutoring and resources/debates) were examined as these were expected to improve higher order cognitive skills of the learners but have minimal demands on tutor time. 
The authors conclude that these techniques appeared not to require excessive levels of tutor input but further studies are planned.

Guldberg, K., \& Pilkington, R. (2007). Tutor roles in facilitating reflection on practice through online discussion. Educational Technology and Society, 10(1), 61-72.

The authors examine the effectiveness of online discussions from the perspective of the impact of the topic selected and the intervention by the facilitator during the discussion. They conclude that if more emphasis is placed on the preparatory work an online tutor undertakes in advance of a discussion that less involvement from them is required during the discussion. The guidance on a general structure for discussion topics that were found to promote effective dialogue is helpful.

Hemphill, L., \& Hemphill, H. (2007). Evaluating The impact of guest speaker postings in online discussions. British Journal of Educational Technology, 38(2), 287293.

The contribution of guest tutors to asynchronous online discussions is examined in this paper. Interestingly, it was found that the critical thinking skills and interest levels of the students were improved by the guest tutors but, even when these tutors were not involved, the students still interacted a great deal and at a higher-order thinking level. The conclusion the authors arrive at is that only occasional, good quality interaction from a guest tutor.

Hughes, G. (2007). Using blended learning to increase learner support and improve retention. Teaching in Higher Education, 12(3), 349-363.

As a result of widening participation, retention is an important issue in higher education. The author discusses an action research project in which effective online tutor support were incorporated into a module and, as a result, module retention was improved. The necessity for a very experienced online facilitator to be involved to ensure success is commented on.

Hughes, M., Ventura, S., \& Dando, M. (2007). Assessing social presence in online discussion groups: a replication study. Innovations in Education and Teaching International, 44(1), 17-29.

This paper is of interest because it explores emotions such as fear, anger and isolation experienced by eLearners. The authors describe how they have tested, adjusted and validated a method for assessing social presence, including emotional state among elearners. The contribution this approach can have to effective facilitation skills is discussed.

Laurillard, D. (2002). Rethinking Teaching for the Knowledge Society. Educause Review 37(1), 16-25. Retrieved May 25, 2007, from

http://www.educause.edu/ir/library/pdf/erm0201.pdf.

The author examines the challenges being faced by Higher Education Institutions as a result of the development of the Knowledge Society, one of which is that their teaching methods have not evolved sufficiently. A careful analysis of how learning technology can be used to adapt teaching methods to meet the needs of the digital age is provided but the author emphasises that academics must be prepared to become reflective practitioners and must be supported in this regard by their institutions..

Littlejohn, A, \& Pegler, C. (2007). Preparing for blended eLearning. London: Routledge.

The authors aim to help facilitators to design and implement effective blended eLearning and their approach is to examine four aspects - space, time, activities and 
tools. Issues of interest discussed include designing quality, effective online learning, devising activities and managing online and offline interactions and a number of case studies are provided. A critical analysis of the strengths of eLearning is provided but the authors are realistic about its limitations.

Lohnes, S., \& Kinzer, C. (2007). Questioning assumptions about students' expectations for technology in college classrooms. Innovate, 3(5). Retrieved May 28, 2007, from http://www.innovateonline.info/index.php?view=article\&id=431

An interesting ethnographic study of how a small group of college students use technology to make meaning of their experience in academic and non-academic spaces is provided. It was found that the physical environment and the students' attitudes to learning and teaching were important factors. The importance of not making general assumptions about the extent to which students would like to see learning technology incorporated into their programmes of study is one of the main conclusions.

Maier, P., \& Warren, A. (2000). Integrating technology in learning and teaching. London: Kogan Page.

This book provides a sound introduction into the use of information technology in educational settings. It presents a wide range of activities, checklists and activities and has a practice based focus. Topics of interest examined are e-moderation, pedagogical frameworks, production of digital learning materials and the development of learning outcome goals.

Mason, R., \& Rennie, F. (2006). e-Learning: the key concepts. New York: Routledge. A useful general reference book and guide as it explains and provides relevant weblinks for all terms and topics relevant to eLearning. The introduction examines the development of eLearning and the current challenges faced and includes suggestions for further reading.

O'Regan, K. (2003). Emotion and eLearning. Journal of Asynchronous Learning Networks, 7(3), 78-92. Retrieved May 21, 2007, from http://www.sloanc.org/publications/jaln/v7n3/v7n3_oregan.asp

The author interviewed 11 online learners and identified a number of common emotions that they experienced regularly - some positive (pride, excitement) and some negative (frustration, anxiety, embarrassment). The excerpts from the interviews conducted are very informative and practical guidelines on how best to avoid negative emotions developing among eLearners are provided. A theoretical consideration of how emotion effects how people learn is also incorporated.

Price, L., Richardson, J., \& Jelfs, A. (2007). Face-to-face versus online tutoring support in distance education. Studies in Higher Education, 32(1) 1-20.

A comparison between the experiences that students on the same distance learning course reported as a result of being provided with either online or face-to-face tutorials is discussed. The students who received face-to-face tutorials reported a better experience. As a result, the need for training in communicating online for both tutors and students is emphasised.

Roberts, T. (2006) (Ed.). Self, peer and group assessment in eLearning. London: Information Science Publishers.

The contributors examine the principal characteristics of assessment approaches which encourage learners to take greater responsibility for their own learning in an online environment. The benefits and problems associated with the assessment 
strategies proposed are examined, case studies are discussed and useful guidelines for effective implementation are provided.

Savin-Baden, M. (2000). Problem-based learning in higher education: untold stories. Buckingham: Open University Press.

The author explores the theory and practice of problem based learning and considers the implications of implementing this approach. Of interest is her discussion of the student experience of 'dislocation' in which students experience frustration and discomfort in coping with novel and unfamiliar learning situations.

Shephard, K., Haslam, P., Hutchings, M., \& Furneaux, C. (2004, April). Synchronous Online Tutorials for Staff Development? Paper presented at the Networked Learning Conference, University of Lancaster, UK. Retrieved April 4, 2006, from http://www.shef.ac.uk/nlc2004/Proceedings/Individual_Papers/Shephard_et_al.htm The authors discuss the formation of collaborative online groups of academics engaged in synchronous online discussions about the use of eLearning tools. The detailed discussion on the benefits and shortfalls of online synchronous communication and the comparison to face-to-face communication is very useful.

Toohey, S. (1999). Designing courses for higher education. Buckingham: The Society for Research into Higher Education \& Open University Press.

The author focuses on the strategic decisions required when designing courses and offers practical advice. The challenges facing course designers and developers are examined and of particular interest is the chapter on making learning opportunities more flexible in which matters such as flexible delivery, resource based learning and online approaches are discussed. 